\title{
Anemia: first manifestation of a left atrial myxoma
}

\section{Ivana Grgić*, \\ Davorka Lulić, \\ Sandro Brusich, \\ Aleksandra Ljubačev, \\ Slavica Kovačić, \\ Luka Zaputović, \\ Teodora Zaninović Jurjević}

University of Rijeka School of Medicine, University Hospital Centre Rijeka, Rijeka, Croatia
RECEIVED:

March 5, 2017

ACCEPTED:

April 6, 2017

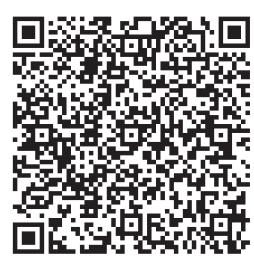

KEYWORDS: myxoma, anemia, cardiac tumors.

CITATION: Cardiol Croat. 2017;12(4):149-150. | https://doi.org/10.15836/ccar2017.149

*ADDRESS FOR CORRESPONDENCE: Ivana Grgić, Klinički bolnički centar Rijeka, Krešimirova 42, HR-51000 Rijeka, Croatia. / Phone: +385-91-577-3799 / E-mail: ivana.grgic.ri@gmail.com

ORCID: Ivana Grgić, http://orcid.org/0000-0002-0035-4445 • Davorka Lulić, http://orcid.org/0000-0002-8937-437X Sandro Brusich, http://orcid.org/0000-0001-7394-6698 • Aleksandra Ljubačev, http://orcid.org/0000-0003-1944-7163 Slavica Kovačić, http://orcid.org/0000-0002-7419-224X • Luka Zaputović, http://orcid.org/0000-0001-9415-9618 Teodora Zaninović Jurjević, http://orcid.org/0000-0001-8359-3910

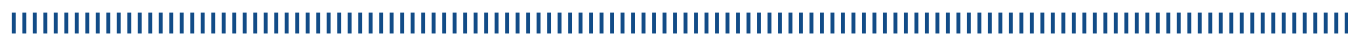
Introduction: Myxomas are the most common benign primary cardiac tumors with the majority (85\%) located in the left atrium. Clinical manifestations are diverse and are consequence of embolic phenomena, intracardiac obstruction or constitutional symptoms. Early diagnosis, most perplexing in a patient with constitutional symptoms, remains an important challenge for the clinician, as they have an excellent prognosis following surgical excision, preventing complications and improving quality of life..$^{-3}$

Case report: We report a case of a 75-year-old female presented with fatigue and weight loss. Symptoms were first attributed to her history of hyperthyroidism. After series of normal hormonal and thyroid ultrasound findings she was referred to gastroenterologist for the evaluation of microcytic anemia (Hb 101g/L). Even though results of fecal occult blood testing were negative, esophagogastroduodenoscopy and colonoscopy were performed subsequently having sent our patient to hematologist for further examinations regarding anemia. After a year of anemia assessment she underwent transthoracic echocardiography which demonstrated an intraatrial mass. Immediately hospitalized, transesophageal echocardiography (Figure 1, Figure 2) and magnetic resonance imaging (Figure 3) were performed. Features of the mass were consistent with notably large myxoma, occupying nearly the entire left atrium and prolapsing across the mitral valve during diastole. Coronary angiography showed no obstructive coronary artery disease. Our patient underwent urgent cardiothoracic surgery with successful excision of atrial mass attached to the interatrial septum, pathologically confirmed myxoma (Figure 4). Cardiac rehabilitation followed immediately after discharge, with normalization of hemoglobin levels.

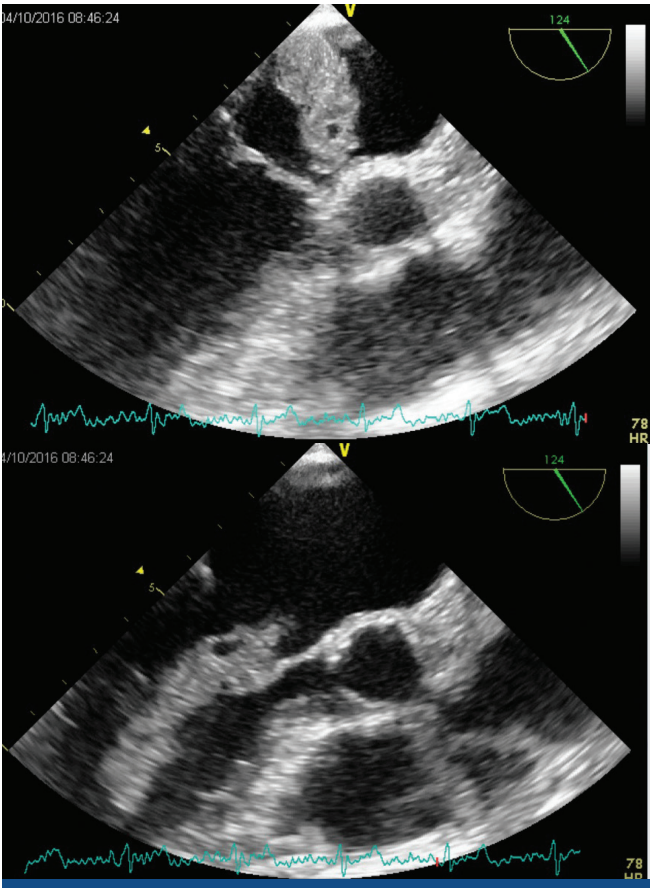

FIGURE 1. Long axis transesophageal echocardiography showing prolapsing atrial myxoma in A) systole and B) diastole.

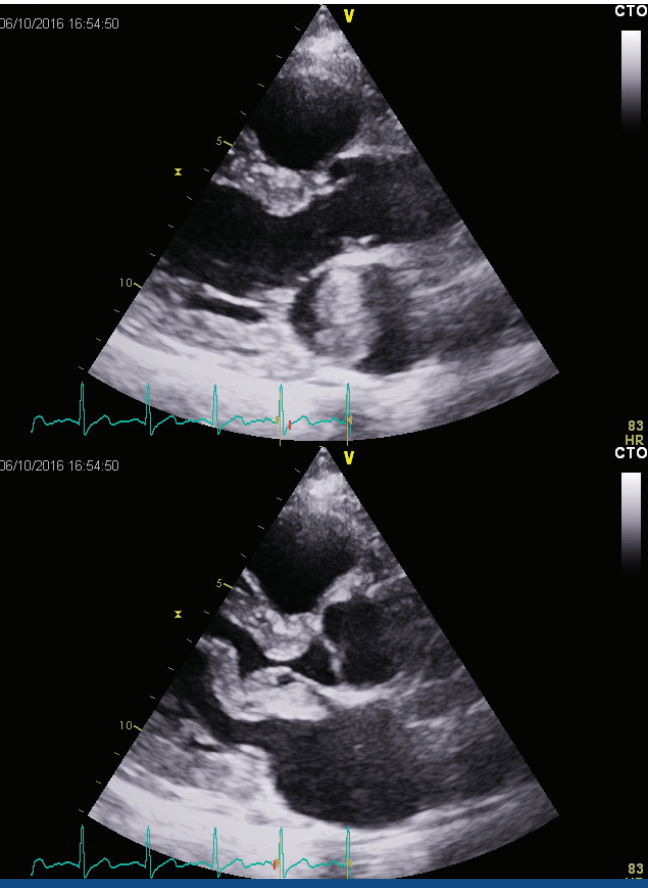

FIGURE 2. Parasternal long axis view with left atrial myxoma in A) systole and B) diastole. 
Conclusion: Diagnosis of atrial myxomas is often challenging due to their asymptomatic nature or nonspecific symptoms presentation. Constitutional symptoms, like weight loss and fatigue and associated laboratory findings (elevated sedimentation rate and anemia) are explained as a result of interleukin- 6 production by cardiac myxoma cells. Although histopathologically benign, complications due to their position and embolization can be fatal. Therefore, prompt complete surgical excision after diagnosis, regardless of whether the patient is symptomatic, is strongly recommended. The present case summons the significance of considering atrial myxoma while investigating a patient presenting with constitutional symptoms and persistent unexplained anemia. Early suspicion supported by echocardiogram may facilitate the diagnosis.
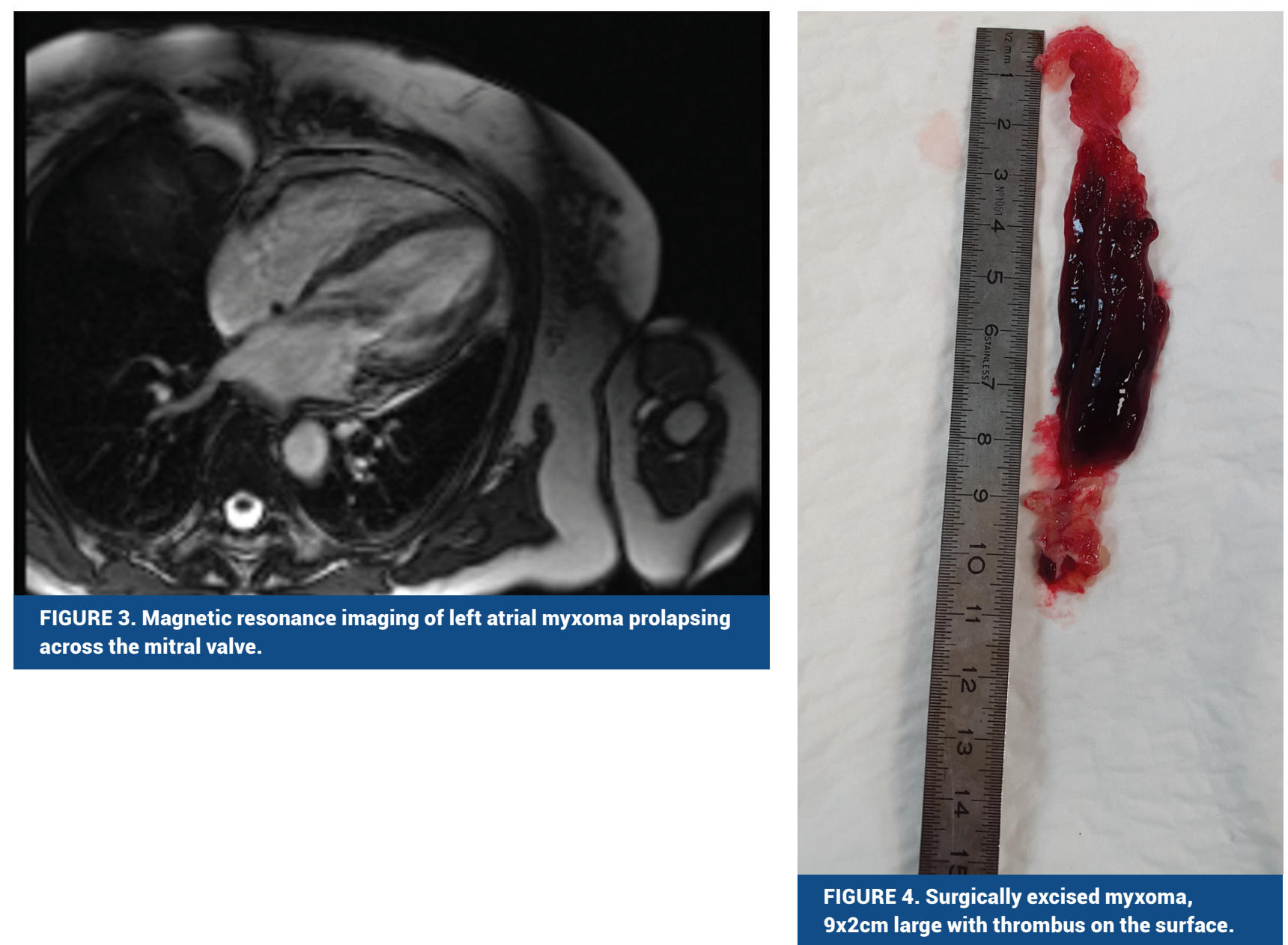

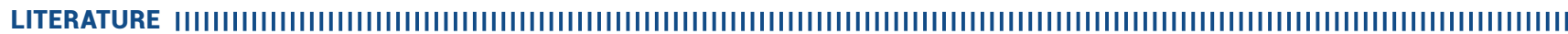

1. Hayek ER, Haas AJ, Kamienski RW. Massive right atrial myxoma presenting as a chronic anemia. J Am Soc Echocardiogr. 2007 Jun;20(6):771.e1-2. https://doi.org/10.1016/j.echo.2006.11.015

2. Mendoza CE, Rosado MF, Bernal L. The role of interleukin-6 in cases of cardiac myxoma. Clinical features, immunologic abnormalities, and a possible role in recurrence. Tex Heart Inst J. 2001;28(1):3-7. https://www.ncbi.nlm.nih.gov/pubmed/11330738

3. Lone RA, Ahanger AG, Singh S, Mehmood W, Shah S, Lone G, et al. Atrial myxoma: trends in management. Int J Health Sci (Qassim). 2008 Jul;2(2):141-51.

https://www.ncbi.nlm.nih.gov/pubmed/21475496 